\title{
Haemorrhagic form of dermatitis herpetiformis
}

\author{
Postać krwotoczna choroby Duhringa
}

Martyna Skręta-Śliwińska, Anna Woźniacka, Agnieszka Żebrowska

Department of Dermatology and Venereology, Medical University of Lodz, Lodz, Poland

Katedra i Klinika Dermatologii i Wenerologii, Uniwersytet Medyczny, Łódź, Polska

Dermatol Rev/Przegl Dermatol 2020, 107, 69-77

DOI: https://doi.org/l 0.5 I |4/dr.2020.93974

\author{
CORRESPONDING AUTHOR/ \\ ADRES DO KORESPONDENCJI: \\ dr hab. n. med. \\ Agnieszka Żebrowska \\ Katedra i Klinika Dermatologii \\ i Wenerologii \\ Uniwersytet Medyczny \\ plac Hallera 1 \\ 90-647 Łódź, Polska \\ tel.: +48504273631 \\ e-mail: zebrowskaaga@wp.pl
}

\begin{abstract}
Introduction. Dermatitis herpetiformis is a chronic autoimmune bullous disease related to gluten intolerance with a polymorphic form of lesions that imitates other dermatoses and causes important diagnostics difficulties.

Objective. To report a case of a very rarely diagnosed haemorrhagic form of Duhring disease, which developed in a 72-year-old man.

Case report. This article presents a description of a patient with lesions located on smooth body skin and scalp, which lasted for several months and had the character of erythematopapular eruptions with a haemorrhagic component and secondary erosions and scabs. The skin lesions had an annular structure and the distribution was symmetrical with the greatest intensity at the elbows, knees, buttocks and thighs. Histopathological examination, direct immunofluorescence, indirect immunofluorescence and the immunoblot method allowed diagnosing Duhring disease. Incorporated pharmacological treatment with dapsone and a gluten-free diet resulted in a significant clinical improvement.

Conclusions. The presented case draws attention to atypical clinical presentation and the appearance time of the first symptoms of dermatitis herpetiformis.
\end{abstract}

\section{STRESZCZENIE}

Wprowadzenie. Opryszczkowate zapalenie skóry jest przewlekłą, autoimmunologiczną chorobą pęcherzową związaną z nietolerancją glutenu. Charakteryzuje się występowaniem polimorficznych zmian skórnych, które imitują inne dermatozy i powodują istotne trudności diagnostyczne.

Cel pracy. Przedstawienie przypadku bardzo rzadko rozpoznawanej krwotocznej postaci choroby Duhringa, która wystąpiła u 72-letniego mężczyzny.

Opis przypadku. W pracy przedstawiono przypadek pacjenta ze zmianami zlokalizowanymi na skórze gładkiej ciała i owłosionej skórze głowy, które utrzymywały się od kilku miesięcy i miały postać wykwitów rumieniowo-grudkowych $\mathrm{z}$ wyraźnym komponentem krwotocznym oraz zmian wtórnych w postaci nadżerek i strupów. Zmiany skórne przybierały układ obrączkowaty, a ich rozmieszczenie było symetryczne z największym nasileniem w obrębie łokci, kolan, pośladków i ud. Badanie histopatologiczne wycinka, badania immunofluorescencji bezpośredniej, immunofluorescencji pośredniej oraz metodą immunoblot 
pozwoliły rozpoznać chorobę Duhringa. Włączone leczenie farmakologiczne z zastosowaniem dapsonu oraz dieta bezglutenowa spowodowały istotną poprawę kliniczną.

Wnioski. Przedstawiony przypadek zwraca uwagę na nietypowość zarówno obrazu klinicznego, jak i czasu wystąpienia pierwszych objawów opryszczkowatego zapalenia skóry.

Key words: dermatitis herpetiformis, Duhring disease, tissue transglutaminase, dapsone, haemorrhagic lesions, gluten intolerance.

Słowa kluczowe: opryszczkowate zapalenie skóry, choroba Duhringa, transglutaminaza tkankowa, dapson, zmiany krwotoczne, nietolerancja glutenu.

\section{INTRODUCTION}

Dermatitis herpetiformis (DH; Duhring disease) belongs to IgA-dependent autoimmune blistering dermatoses. Dermatitis herpetiformis is most common in the North European population [1]. The disease usually surfaces in puberty, however, it may develop at every age. Dermatitis herpetiformis is also the most common blistering disease in children. The proportion of incidence in men and women equals $3: 2$. The course of the disease is chronic and with a tendency towards exacerbations and remissions $[2,3]$.

Dermatitis herpetiformis has a complex etiopathogenesis. Environmental, genetic, and immunological factors are taken into account in the development of the disease [3].

The most common cause of $\mathrm{DH}$ is gluten intolerance. Gluten is a mixture of plant proteins built from gliadin's amino acids and glutenin that are found in cereal grains such as: wheat, barley, oats, rye, and in malt. Examples of comestible products that contain gluten include: flour, ready-made foods, cold cuts, sweets, dairy, and alcohol [4]. Patients with DH suffer from gluten-dependent enteropathy [3]. All patients have anatomical changes in the small intestine that take the form of intestinal villi atrophy, however, gastroenterological symptoms are usually mild or completely absent [5]. Strict and long-term gluten-free diet allows for achieving disease remission. Unusually, some patients experience spontaneous improvement, however, this process has not been fully explained yet.

A strong connection between this disease entity and individuals with specific histocompatibility antigens, HLA, has been confirmed. HLA DR3 and HLA DQw2 predispose for the disease development and have been detected in $80-90 \%$ of cases; whereas HLA-B8 and HLA DQ8 are present in $10-20 \%$ of patients $[3,4]$. Participation of the genetic factor is

\section{WPROWADZENIE}

Opryszczkowate zapalenie skóry (choroba Duhringa, dermatitis herpetiformis - DH) należy do autoimmunologicznych dermatoz pęcherzowych zależnych od IgA. Choroba Duhringa jest najczęściej stwierdzana w populacji północnoeuropejskiej [1]. Przeważnie występuje w okresie dojrzewania, jednak może pojawić się w każdym wieku. Dermatitis herpetiformis jest także najczęstszą chorobą pęcherzową stwierdzaną u dzieci. Stosunek liczby chorujących mężczyzn do kobiet wynosi 3 : 2. Przebieg choroby jest przewlekły, $z$ tendencją do występowania zaostrzeń i remisji [2, 3].

Opryszczkowate zapalenie skóry ma złożoną etiopatogenezę. W rozwoju choroby bierze się pod uwage czynniki środowiskowe, genetyczne oraz immunologiczne [3].

Podstawową przyczyną DH jest nietolerancja glutenu. Gluten jest mieszaniną białek roślinnych zbudowanych z aminokwasów gliadyny oraz gluteniny, które znajdują się w nasionach zbóż, takich jak pszenica, jęczmień, owies, żyto, a także w słodzie. Przykładami produktów spożywczych, które zawierają gluten, są: mąka, wyroby garmażeryjne, wędliny, słodycze, nabiał oraz alkohol [4]. U pacjentów z DH występuje glutenozależna enteropatia [3]. U wszystkich chorych stwierdza się anatomiczne zmiany w jelicie cienkim w postaci zaniku kosmków, jednak objawy gastroenterologiczne są zazwyczaj łagodne lub całkowicie nieobecne [5]. Ścisła i długotrwała dieta bezglutenowa pozwala osiągnąć remisję choroby. Wyjątkowo u niektórych pacjentów dochodzi do samoistnej poprawy, jednak zjawisko to nie zostało do tej pory wyjaśnione.

Wykazano silny związek między występowaniem tej choroby a obecnością określonych antygenów zgodności tkankowej HLA. Do rozwoju choroby predysponuje HLA DR3 i HLA DQw2, które wykrywa się w 80-90\% przypadków, oraz HLA-B8 i HLA DQ8, które są obecne u 10-20\% pacjentów [3, 4]. Udział 
confirmed by the fact that in Japan, where the abovementioned histocompatibility antigens are almost non-existent, DH is rare [2]. Additionally, it was showed that the risk of disease development in the first-degree relatives of patients might be 15 times higher as compared with the general population [6].

DH-patients have been proved to have an increased incidence of concomitant autoimmune disease. Those include thyroid diseases, type 1 diabetes, malignant anaemia, lupus erythematosus, Sjögren's syndrome, and leucoderma [3].

Furthermore, it has been confirmed that iodine is a factor that induces and intensifies skin lesions. It is contained in drugs, comestible products, and seaside air. Concomitant infectious diseases and stress also contribute to lesion intensification in $\mathrm{DH}$ [7].

\section{OBJECTIVE}

The aim of the article is to present an extremely rare case of haemorrhagic lesions in DH that developed unusually late in a 72-year-old patient, and to present a review of current literature.

\section{CASE REPORT}

A 72-year-old male reported to the Department of Dermatology and Venereology, Medical University of Lodz, due to polymorphic skin lesions that had been present for several months. Cutaneous lesions were accompanied by a burning sensation and intensified pruritus assessed by the patients as $7 / 10$ points on the Visual Analogue Scale (VAS). The patient did not associate the appearance of lesions with any factors he denied prior and concomitant infections, usage of new cosmetics, drugs, and contact with preparations that have toxic or allergic effects.

In the medical history the patients confirmed: stable coronary arterial disease, paroxysmal atrial fibrillation, arterial hypertensions, hyperlipidaemia, degenerative spine disease, and prostate gland hypertrophy. In the past, the patient experienced brain infarction and was treated due to duodenal ulcers. Moreover, the patient underwent the following procedures: coronary artery bypass graft, several percutaneous coronary interventions, appendectomy, and a surgery of inguinal hernia. The patient denied dermatological diseases in the family. Prior to being admitted to the Department, the patient was treated on an outpatient basis with antihistamine preparations and topical glucocorticosteroids without significant improvements.

Upon admission, erythematopapular lesions with a clear haemorrhagic component and erosions as well as scabs were confirmed on the smooth skin (figs. 1, 2). The lesions had an annular structure and symmetrical czynnika genetycznego potwierdza fakt, że w Japonii, gdzie wyżej wymienione antygeny zgodności tkankowej prawie nie występują, DH należy do rzadkości [2]. Ponadto wykazano, że ryzyko wystąpienia schorzenia u krewnych pierwszego stopnia osób chorych może być nawet 15-krotnie wyższe w porównaniu z populacją ogólną [6].

U chorych na DH udowodniono zwiększoną częstość współwystępowania innych chorób autoimmunologicznych: chorób tarczycy, cukrzycy typu 1, niedokrwistości złośliwej, tocznia rumieniowatego, zespołu Sjögrena i bielactwa [3].

Stwierdzono także, że czynnikiem indukującym oraz nasilającym zmiany skórne jest jod, który znajduje się w lekach, produktach spożywczych oraz nadmorskim powietrzu. Do nasilenia zmian w przebiegu DH przyczyniają się również współistniejące choroby infekcyjne i stres [7].

\section{CEL PRACY}

Celem pracy jest przedstawienie niezwykle rzadkiego przypadku zmian o charakterze krwotocznym w przebiegu $\mathrm{DH}$, z nietypowym późnym rozwojem pierwszych objawów u 72-letniego pacjenta oraz przegląd aktualnego piśmiennictwa.

\section{OPIS PRZYPADKU}

Do Kliniki Dermatologii i Wenerologii Uniwersytetu Medycznego w Łodzi zgłosił się 72-letni mężczyzna z powodu utrzymujących się od kilku miesięcy polimorficznych zmian skórnych. Wykwitom towarzyszyło uczucie pieczenia oraz nasilony świąd, oceniany przez pacjenta na 7/10 pkt w wizualnej skali analogowej (Visual Analogue Scale - VAS). Chory nie wiązał pojawienia się zmian z żadnym czynnikiem - negował poprzedzające i współistniejące infekcje, stosowanie nowych kosmetyków, leków oraz kontakt z preparatami o działaniu toksycznym lub alergicznym.

W wywiadzie pacjent podawał: stabilną chorobę wieńcową, napadowe migotanie przedsionków, nadciśnienie tętnicze, hiperlipidemię, chorobę zwyrodnieniową kręgosłupa i przerost gruczołu krokowego. W przeszłości przeszedł udar niedokrwienny mózgu oraz był leczony z powodu owrzodzenia dwunastnicy. Ponadto chory przeszedł pomostowanie aortalno-wieńcowe, kilkukrotnie zabiegi koronaroplastyki, appendektomię oraz operację przepukliny pachwinowej. Pacjent negował występowanie chorób dermatologicznych w rodzinie. Do czasu przyjęcia do Kliniki był leczony $w$ trybie ambulatoryjnym preparatami przeciwhistaminowymi oraz miejscowo glikokortykosteroidami bez istotnej poprawy.

Przy przyjęciu na skórze gładkiej ciała stwierdzono obecność zmian o charakterze rumieniowo-grudko- 


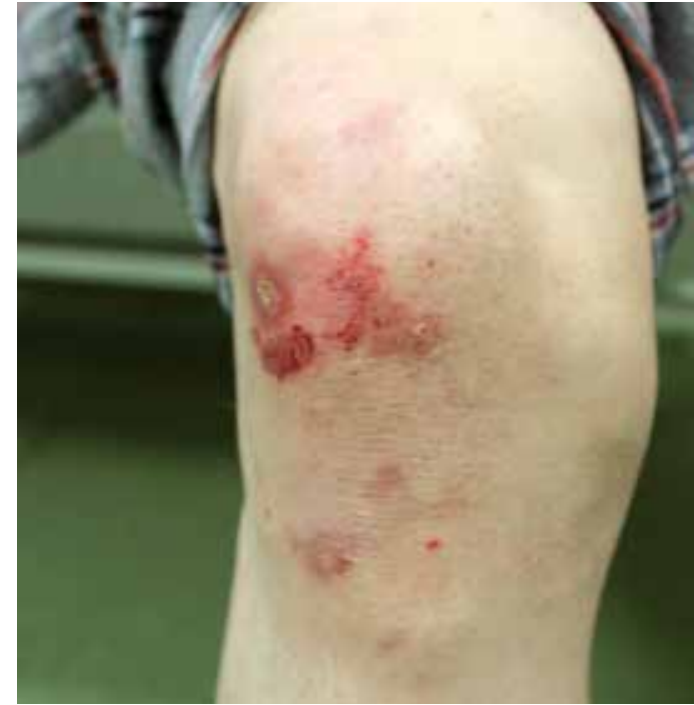

Figure I. Erythematopapular lesions with a haemorrhagic component on the knee

Rycina I. Zmiany rumieniowo-grudkowe z komponentem naczyniowym w obrębie kolana

distribution with the greatest intensity at the elbows, knees, buttocks and thighs. Inconspicuous skin lesions were observed on the forearms and dorsal surfaces of palms. Some lesions merged to form bigger foci. Additionally, impetiginisation within some lesions was observed; it was associated with a secondary bacterial infection caused by a superinfection triggered by obstinate scratching. Those lesions took the form of honey- and yellow-coloured scabs (fig. 3). At the boarder of the smooth skin and the scalp, single erythematous papulae were observed.

Inconspicuous fine-flake desquamation of the epidermis was present on the scalp. Physical examination did not reveal significant abnormalities from the norm. The patient did not report any pain cause by the gastrointestinal tract.

Values of basic laboratory tests were within normal limits. Direct immunofluorescence test of the healthy skin sample taken from the lesion area on the buttock showed the presence of IgA (++) granular deposits at the tops of papillae (MP Biomedicals, USA) (fig. 4). Indirect immunofluorescence test results showed the serum presence of $\operatorname{IgA}$ antibodies directed towards the endomysium of smooth muscles (IgA EmA) with the 1/20 titre, and IgA antibodies directed towards gliadin with the 1/20 titre (Euroimmun, Germany). The examination utilizing the immunoblot method confirmed the presence of antibodies directed towards tissue transglutaminase IgA (anti-tTG), and antibodies directed towards gliadin IgA and IgG. The presence of other antibodies was not confirmed. Histopathological examination of a skin sample with a lesion showed smoothening of the epidermis with a crevicular exfoliation of all epidermal layers. Papillae skin was oedematous in places, with neu-

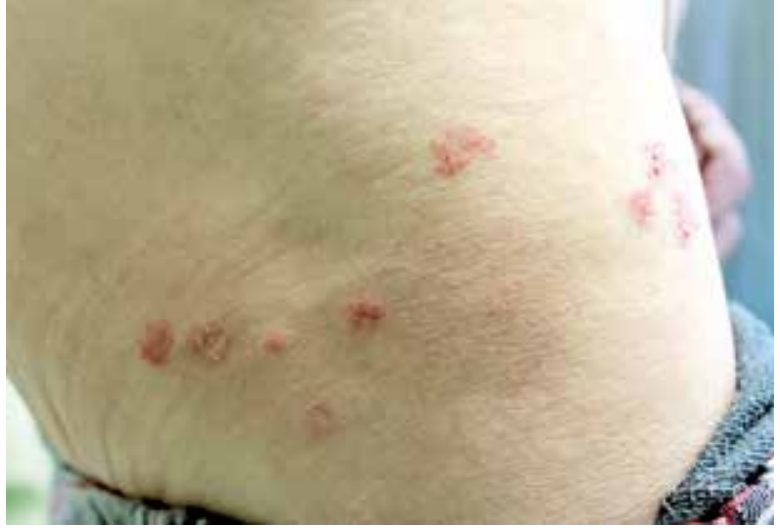

Figure 2. Lesions on the thigh and right buttock

Rycina 2. Zmiany w obrębie uda i pośladka prawego

wym z wyraźnym komponentem krwotocznym oraz nadżerek i strupów (ryc. 1, 2). Układ zmian był obrączkowaty, symetryczny, z największą predylekcją do okolicy łokci, kolan, pośladków i ud. Dyskretne wykwity obserwowano w obrębie przedramion oraz powierzchni grzbietowej rąk. Część zmian zlewała się w większe ogniska. Dodatkowo obserwowano impetyginizację w obrębie niektórych zmian skórnych spowodowaną wtórną infekcją bakteryjną związaną z nadkażeniem wywołanym uporczywym drapaniem. Te zmiany miały postać miodowożółtych strupów (ryc. 3). Na granicy skóry gładkiej i skóry owłosionej głowy obserwowano pojedyncze grudki na rumieniowym podłożu.

W obrębie skóry owłosionej głowy występowało dyskretne, drobnopłatowe złuszczanie naskórka. $W$ badaniu internistycznym nie stwierdzono istotnych odchyleń od stanu prawidłowego. Pacjent nie zgłaszał żadnych dolegliwości ze strony przewodu pokarmowego.

Wyniki podstawowych badań laboratoryjnych mieściły się $\mathrm{w}$ granicach normy. W badaniu immunofluorescencji bezpośredniej wycinka zdrowej skóry z okolicy zmian na pośladku wykazano obecność ziarnistych złogów IgA (++) w szczytach brodawek skórnych (MP Biomedicals, USA) (ryc. 4). W badaniu metodą immunofluorescencji pośredniej stwierdzono w surowicy obecność przeciwciał $w$ klasie IgA skierowanych przeciwko endomysium mięśni gładkich (IgA Em A) w mianie 1/20 oraz przeciwciał $w$ klasie IgA skierowanych przeciwko gliadynie w mianie 1/20 (Euroimmun, Germany). Badanie metodą immunoblot wykazało obecność przeciwciał skierowanych przeciwko transglutaminazie tkankowej (anty-tTG) w klasie IgA i przeciwciał skierowanych przeciwko gliadynie w klasie IgA i IgG. Nie stwierdzono obecności innych przeciwciał. W badaniu histopatologicznym wycinka pobranego ze zmienionej chorobowo skóry obserwowano wygładzenie naskórka ze szczelinowatym odwarstwieniem wszystkich warstw naskórka. Skóra brodawek była miejscami obrzęknięta, z naciekami neutrofilów, głównie w szcze- 


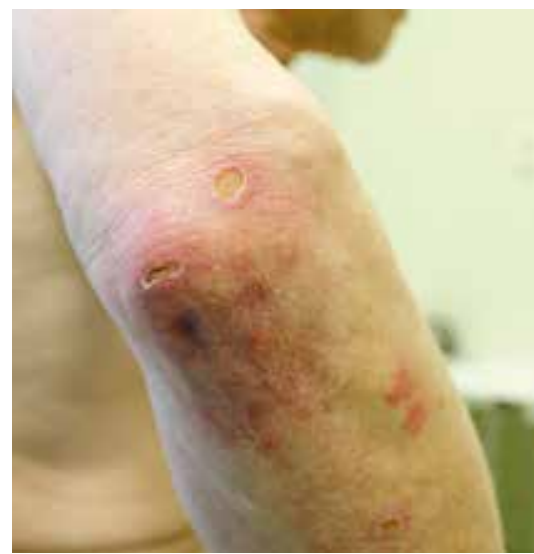

Figure 3. Erythematopapular lesions and erosions covered with honey- and yellow-coloured scabs on the right elbow

Rycina 3. Zmiany rumieniowo-grudkowe oraz nadżerki pokryte miodowożóltymi strupami w obrębie łokcia prawego

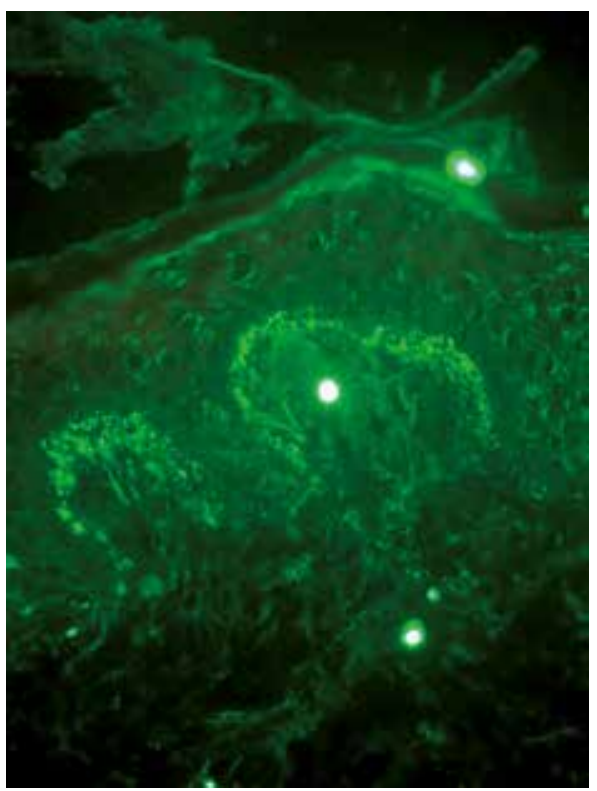

Figure 4. Direct immunofluorescence - granular IgA deposits at the tops of papillae

Rycina 4. Badanie immunofluorescencyjne bezpośrednie - ziarniste złogi IgA w szczytach brodawek

trophil infiltrations mostly in the crevasses and papillae (fig. 5). Acantholytic cells were not confirmed. According to the pathomorphologist's assessment, the holistic image did not have the signs of pemphigus: it could suggest pemphigoid or $\mathrm{DH}$.

On the basis of clinical presentation and results of additional test, DH was diagnosed. Other vesical and vascular diseases were excluded. Gluten-free diet was started; due to considerable severity of lesions, a decision was made to simultaneously administer dapsone in the dose of $100 \mathrm{mg} /$ day, and then, $50 \mathrm{mg} /$ day. In addition, intensive topical treatment with glucocorticosteroids was started together with application of combined drugs containing also antimicrobial substances - due to superinfection of the lesions.

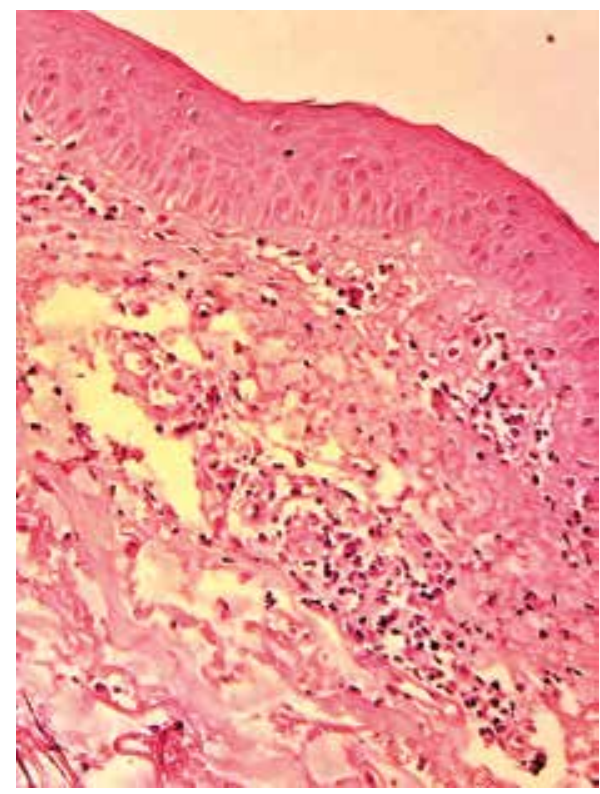

Figure 5. Histopathological image of a skin sample with lesions haematoxylin and eosin staining, magnified $100 \times$

Rycina 5. Obraz histopatologiczny wycinka skóry zmienionej chorobowo - barwienie hematoksyliną i eozyną, powiększenie $100 \times$

linach i brodawkach (ryc. 5). Nie stwierdzono komórek akantolitycznych. Całościowy obraz według oceny patomorfologa nie miał cech pęcherzycy, mógł sugerować pemfigoid lub DH.

Na podstawie obrazu klinicznego oraz wyników badań dodatkowych rozpoznano DH. Wykluczono inne choroby pęcherzowe, a także schorzenia o etiologii naczyniowej. Zastosowano dietę bezglutenową oraz ze względu na duże nasilenie zmian postanowiono o jednoczesnym podaniu dapsonu w dawce $100 \mathrm{mg} /$ dobę, a następnie $50 \mathrm{mg} /$ dobę. Dodatkowo wdrożono intensywne leczenie miejscowe glikokortykosteroidami oraz - w związku z nadkażeniem zmian - lekami łączonymi zawierającymi substancje przeciwdrobnoustrojowe. 
During the subsequent days of the therapy, a gradual improvement in the skin condition was observed. Erythematopapular lesions began to absorb themselves, erosions started to be covered by the epidermis, and no new lesions were observed. Already after several days of taking dapsone, the patient noticed significant decrease in pruritus (VAS - 2/10 points). Due to an increased methemoglobin concentration in follow-up exams $(3.2 \%)$, it was decided to decrease the Dapsone dose down to $25 \mathrm{mg}$ /day. Complete remission of skin lesions with remaining post-inflammatory discolourations was observed after 2 months of the treatment.

\section{DISCUSSION}

Skin lesions in the DH are most often polymorphous. They include: papulae, erythemas, blisters, urticarial eruptions, and numerous secondary lesions caused by persistent scratching. Haemorrhagic reactions, such as the ones in the presented case, are less commonly observed. A distribution of lesions DH is characteristic as they are found symmetrically and their distribution is festoon-like or herpetiform-like. Extensor surfaces of limb, knees, elbows, buttocks, and scalp are areas predisposed for the appearance of lesions [1]. Skin eruptions are accompanied by pruritus of a burning sensation. Intensity of reported pain is often incommensurable with intensity of skin lesions. Accompanying pruritus and consequent need to scratch oneself result in the absence of blistering as in the described case. Then, erosions and ulcers dominate the clinical presentation that may indicate a wrong diagnosis.

Mucous membranes are usually free from lesions. In the majority of cases there are also no gastrointestinal symptoms. If those appear, they mostly concern children and take the form of diarrhoea, stomachache, and bloating. The lack of extracutaneous symptoms makes it difficult to connect skin lesions with gluten intolerance.

Etiopathogenesis of eruptions in this disease is complex and not fully known. Immunological mechanisms leading to tissue lesions have not been described yet.

In $\mathrm{DH}$, during a direct immunofluorescence test of a healthy skin sample presence of granular IgA deposits in the papillary dermis can be observed. Deposits are usually limited to the tops of papillae. In less than $5 \%$ of cases of DH-patients, a linear pattern of IgA antibodies is detected, what should be differentiated from a linear IgA bullous dermatosis [8]. IgA deposits may be accompanied by less numerous $\mathrm{C} 3$ deposits; IgG and IgM are less commonly detected. Antibody deposits have a tendency to persist despite successful treatment and gluten-free diet $[2,3]$.
W kolejnych dniach terapii obserwowano stopniową poprawę stanu skóry. Zmiany rumieniowo-grudkowe zaczęły się powoli wchłaniać, nadżerki pokrywały się naskórkiem, nie obserwowano wysiewu nowych zmian. Już po kilku dniach przyjmowania dapsonu pacjent zauważył znaczne zmniejszenie świądu (VAS - 2/10 pkt). Ze względu na podwyższone stężenie methemoglobiny $\mathrm{w}$ badaniach kontrolnych (3,2\%) zdecydowano o zmniejszeniu dawki dapsonu do $25 \mathrm{mg} /$ dobę. Całkowite ustąpienie zmian skórnych z pozostawieniem przebarwień pozapalnych obserwowano po 2 miesiącach leczenia.

\section{OMÓWIENIE}

Zmiany skórne w przebiegu DH mają najczęściej charakter polimorficzny. Mogą się pojawiać grudki, rumienie, pęcherzyki, wykwity pokrzywkowe oraz liczne wykwity wtórne spowodowane uporczywym drapaniem. Rzadziej obserwuje się odczyny o charakterze krwotocznym, takie jak w prezentowanym przypadku. Typowe dla DH jest symetryczne rozmieszczenie wykwitów, które układają się festonowato lub opryszczkowato. Okolicami predysponowanymi do pojawienia się zmian są powierzchnie wyprostne kończyn, kolana, łokcie, pośladki oraz skóra owłosiona głowy [1]. Zmianom skórnym towarzyszy świąd oraz uczucie pieczenia. Intensywność zgłaszanych dolegliwości jest często niewspółmierna do nasilenia zmian skórnych. Z obecności świądu wynika konieczność drapania, co powoduje, że często pęcherzyki nie są obecne, tak jak w opisywanym przypadku. Wówczas w obrazie klinicznym przeważają nadżerki i owrzodzenia, które mogą sugerować błędne rozpoznania.

Błony śluzowe zwykle są wolne od zmian. W większości przypadków nie występują także objawy ze strony przewodu pokarmowego. Jeżeli się one pojawiają, dotyczą najczęściej dzieci i mają postać biegunek, bólów brzucha i wzdęć. Brak objawów pozaskórnych powoduje, że trudno jest powiązać zmiany z nietolerancją glutenu.

Etiopatogeneza zmian skórnych w tej chorobie jest złożona i nie w pełni poznana. Nadal wyjaśniane są mechanizmy immunologiczne prowadzące do wystąpienia zmian tkankowych.

$\mathrm{W}$ badaniu metodą immunofluorescencji bezpośredniej wycinka skóry niezmienionej pacjentów z DH obserwuje się obecność ziarnistych złogów IgA w warstwie brodawkowatej skóry właściwej. Złogi są zazwyczaj ograniczone do szczytów brodawek. U mniej niż 5\% chorych na DH wykrywany jest linijny układ przeciwciał IgA, co należy różnicować z linijną IgA dermatozą pęcherzową [8]. Złogom IgA mogą towarzyszyć mniej liczne złogi C3, rzadziej wykrywane są IgG lub IgM. Złogi przeciwciał mają tendencję do 
IgA antibodies directed towards the endomysium of smooth muscles and tissue as well as epidermal transglutaminase are detected in the bloodstream of patients suffering from DH. Antibodies against the endomysium are highly specific and their appearance is induced by gluten [9].

The presence of autoantibodies against tissue transglutaminase is strictly connected with the activity of the disease. The level of anti-tTG may be measured by means of ELISA that is characterized by $90 \%$ of specificity and sensitivity within the range of $47-95 \%$ [4]. Levels of antibodies against tissue transglutaminase correlate with the level of intensity of histopathological lesions in the mucosa of the jejunum in biopsy samples taken from $\mathrm{DH}$-patients, and with the level of antibodies against the endomysium of smooth muscles [10]. The titre decreased under the influence of effective treatment, and increased with subsequent gluten provocations, and thus, it may be used for assessing whether the patient observed dietary guidelines $[11,12]$.

Characteristic features of DH in the histopathological image include the presence of subcutaneous vesicae with micro-abscesses in the skin papillae. Dominating inflammatory cells include neutrophils; eosinophils are less popular. Leucocyte infiltrations are usually accompanied by fibrosis and dilation of capillaries [13].

The diagnosis is made on the basis of clinical presentation, and histopathological as well as immunological test results [14]. Differential diagnostics should take into account linear IgA bullous dermatosis, herpetiform pemphigus, erythema multiforme bullosum, prurigo, lichen planus annularis, bullous lichen planus, and more common disease entities such as eczematous lesions and scabies. Differentiation within autoimmune bullous diseases only on the basis of clinical symptoms is impossible. Immunopathological tests are of the essence.

Erythema multiforme, just like DH, is characterized by a symmetrical distribution of lesions; however, its most common locations are distal parts of upper and lower limbs. It appears suddenly, is usually associated with an infection or drugs taken, has an acute course, and is accompanied by usual general symptoms such as fever and joint pain. In case of prurigo there are no blisters, and erosions, hypertrophic papulae and scabs dominate the presentation. The disease is chronic with no tendencies to subside.

In cases of lichen planus annularis and bullous lichen planus, characteristic Wickham striae are observed within glistering multilateral papulae that may be distributed linearly. In about half of the cases, the mucosa is also involved; linear or treelike whitening of the epidermis is confirmed on the mucosa. ciągłego utrzymywania się mimo stosowania skutecznego leczenia oraz diety bezglutenowej $[2,3]$.

W krwiobiegu pacjentów z DH wykrywane są przeciwciała IgA skierowane przeciwko endomysium mięśni gładkich oraz przeciwko transglutaminazie tkankowej i naskórkowej. Przeciwciała przeciwko endomysium są wysoce swoiste i ich powstawanie jest indukowane przez gluten [9].

Obecność autoprzeciwciał przeciwko transglutaminazie tkankowej jest ściśle związana z aktywnością choroby. Poziom anty-tTG można zmierzyć metodą ELISA, która charakteryzuje się ponad 90-procentową swoistością i czułością w przedziale 47-95\% [4]. Poziomy przeciwciał przeciwko transglutaminazie tkankowej korelują ze stopniem nasilenia zmian histopatologicznych w błonie śluzowej jelita czczego z próbek biopsyjnych chorych na DH oraz z poziomem przeciwciał przeciwko endomysium mięśni gładkich [10]. Ich miano zmniejsza się pod wpływem efektywnego leczenia, a wzrasta przy kolejnych prowokacjach glutenem, dlatego może służyć do oceny przestrzegania zaleceń dietetycznych przez pacjenta $[11,12]$.

Charakterystyczne cechy DH w obrazie histopatologicznym to obecność pęcherzy podnaskórkowych z mikroropniami w brodawkach skórnych. Do dominujących komórek zapalnych należą neutrofile, rzadziej obserwowane są eozynofile. Naciekom leukocytów zwykle towarzyszy zwłóknienie i rozszerzenie naczyń włosowatych [13].

Diagnoza stawiana jest na podstawie obrazu klinicznego, wyników badania histopatologicznego oraz badań immunologicznych [14]. W różnicowaniu należy wziąć pod uwagę linijną IgA dermatozę pęcherzową, pęcherzycę opryszczkowatą, rumień wielopostaciowy wysiękowy, świerzbiączkę, postać obrączkowatą i pęcherzową liszaja płaskiego, a także częstsze jednostki chorobowe, takie jak zmiany wypryskowe i świerzb. Różnicowanie w obrębie autoimmunologicznych chorób pęcherzowych wyłącznie na podstawie objawów klinicznych nie jest możliwe. Podstawowe znaczenie mają badania immunopatologiczne.

Rumień wielopostaciowy, podobnie jak $\mathrm{DH}$, charakteryzuje się symetrycznym układem zmian, jednak najczęstszą lokalizacją są odsiebne części kończyn górnych i dolnych. Pojawia się nagle, zazwyczaj w związku z infekcją bądź przyjętymi lekami, ma ostry przebieg i towarzyszą mu zwykle objawy ogólne, takie jak gorączka lub bóle stawowe. W przypadku świerzbiączki nie występują pęcherze, a w obrazie przeważają nadżerki, hipetroficzne grudki oraz strupy. Choroba ma przebieg przewlekły, bez skłonności do ustępowania.

W obrazie liszaja płaskiego obrączkowatego i pęcherzowego obserwuje się charakterystyczną siateczkę Wickhama w obrębie błyszczących, wielobocznych grudek, które mogą układać się linijnie. U około połowy pacjentów zajęte są również śluzówki, na któ- 
Eczema is usually associated with specific allergic and non-allergic factors, and lesions within its course are usually disseminated and do not have a herpetiform pattern. Then, scabies is characterized by itch mite track-like burrows, papulae, and neurotic excoriations that are most often found within fingers, wrists, skin folds, genital areas, and buttocks. The lesions are accompanied by pruritus that intensifies at night and after the body is warmed up [2,3].

In case of haemorrhagic lesions, lichen aureus and erythema elevatum diutinum should be excluded. Lichen aureus is counted among pigmented purpuric dermatoses, and its clinical presentation is dominated by ecchymoses, pigmented lesions, haemorrhagic well-defined elevated gold and brown papulae that are distributed linearly and mostly cover distal sections of limbs. Erythema elevatum diutinum is a disease associated with vasculitis characterized by symmetrical papulae, nodes, haemorrhagic lesions and ulcers found within knees, elbows, dorsal parts of palms, feet, and buttocks. Similarly to $\mathrm{DH}$, the lesions are concomitant with pruritus $[2,3]$.

It should be noted that the clinical presentation in the described patient was atypical. In the presented case there were no blisters, and haemorrhagic skin lesions resembled eruptions present in erythema elevatum diutinum and lichen aureus, what caused diagnostics and outpatient treatment difficult. Furthermore, patient's age at which the disease appeared was atypical.

Gluten-free diet is an important part of treatment in DH. Patients' level of gluten intolerance is varied. Some of them require restrictive diet, whereas in others a diet with decreased gluten content is sufficient. After a couple of months of following the diet, skin lesions subside, serum antibody concentration lowers, and histopathological presentation of the jejunal mucosa improves. The diet alleviates disorders in the absorption of necessary nutrients, and hence, it prevents iron, folic acid and vitamin $\mathrm{B}_{12}$ insufficiencies.

In case the observed elimination diet does not bring satisfactory therapeutic effects or when symptoms and signs are intensified, pharmacological treatment is commenced. Dapsone is the drug of choice. A recommended dose is $0.5-2 \mathrm{mg} / \mathrm{kg}$ body weight. Prior to administration of dapsone, CBC should be performed and the level of liver enzymes should be assessed. The use of dapsone is associated with the risk of side effects that include: methemoglobinemia, haemolytic anaemia, agranulocytosis, kidney damage, and systemic neuropathy. Methemoglobinemia occurs most commonly in the clinical practice [15] Dermatological care and close monitoring of the treatment are necessary to ensure safe and effective use of the drug. During the therapy, blood morphology, methemoglobin level and liver markers should rych stwierdza się linijne lub drzewkowate zbielenia nabłonka.

Wyprysk jest zazwyczaj związany z konkretnymi czynnikami alergicznymi i niealergicznymi, zmiany zwykle są rozsiane i nie mają układu opryszczkowatego. Świerzb natomiast cechuje się występowaniem nor świerzbowcowych, grudek oraz przeczosów, najczęściej w obrębie palców rąk, nadgarstków, fałdów skórnych, okolic narządów płciowych oraz pośladków. Zmianom towarzyszy świąd nasilający się $\mathrm{w}$ godzinach nocnych i po rozgrzaniu ciała $[2,3]$.

W przypadku zmian o charakterze krwotocznym należy wykluczyć liszaj złocisty (lichen aureus) oraz rumień wyniosły i długotrwały (erytema elevatum et diutinum). Liszaj złocisty zaliczany jest do plamic barwnikowych, a w jego obrazie klinicznym przeważają wybroczyny, zmiany barwnikowe, krwotoczne oraz dobrze odgraniczone, wyniosłe, złocistobrązowe grudki, które układają się linijnie i zajmują głównie dystalne części kończyn. Rumień wyniosły i długotrwały jest chorobą związaną z zapaleniem naczyń, charakteryzującą się symetrycznymi grudkami, guzkami, zmianami krwotocznymi oraz owrzodzeniami zlokalizowanymi w obrębie kolan, łokci, grzbietów dłoni, stóp, pośladków. Podobnie jak w DH zmianom towarzyszy świąd [2, 3].

Warto zwrócić uwagę, że obraz kliniczny u opisywanego pacjenta nie był typowy. W przedstawionym przypadku nie występowały pęcherzyki, a zmiany skórne o charakterze krwotocznym przypominały wykwity występujące w przebiegu rumienia wyniosłego i długotrwałego oraz liszaja złocistego, co sprawiało problemy diagnostyczne i lecznicze w warunkach ambulatoryjnych. Ponadto wiek pojawienia się choroby w opisywanym przypadku nie był typowy.

Istotne w leczeniu DH jest zastosowanie diety bezglutenowej. Stopień nietolerancji glutenu u chorych jest zróżnicowany. Część z nich wymaga stosowania bardzo restrykcyjnej diety, $u$ innych wystarczająca jest dieta z obniżoną zawartością glutenu. Po kilku miesiącach stosowania diety zmiany skórne ustępują, zmniejszają się stężenia przeciwciał krążących w surowicy i widoczna jest poprawa w obrazie histopatologicznym błony śluzowej jelita czczego. Dieta łagodzi zaburzenia wchłaniania niezbędnych składników odżywczych, w związku z czym zapobiega niedoborom żelaza, kwasu foliowego i witaminy $\mathrm{B}_{12}$.

W przypadku braku zadowalającego efektu terapeutycznego przy stosowaniu diety eliminacyjnej lub gdy objawy przedmiotowe i podmiotowe są bardzo nasilone, włączane jest leczenie farmakologiczne. Lekiem $\mathrm{z}$ wyboru jest dapson. Rekomendowana dawka wynosi 0,5-2 mg/kg m.c. Przed rozpoczęciem podawania leku należy wykonać pełną morfologię oraz oznaczyć stężenie enzymów wątrobowych. Stosowanie dapsonu wiąże się z ryzykiem wystąpienia działań niepożądanych, do których należą: methemoglobinemia, anemia hemolitycz- 
be monitored twice a year [14]. In case of dapsone intolerance, alternative treatment may utilize sulfapyridine, a combination of tetracycline with nicotinamide or cyclosporine. It should be a lifelong treatment. Conducted studies showed that the majority of patients is unable to tolerate gluten after a long-term observance of the elimination diet. Consequently, lifelong gluten-free diet is justified in all patients affected by $\mathrm{DH}[16]$.

\section{CONFLICT OF INTEREST}

The authors declare no conflict of interest. na, agranulocytoza, uszkodzenie nerek oraz obwodowa neuropatia. W praktyce klinicznej najczęściej występuje methemoglobinemia [15]. Opieka dermatologiczna i ścisłe monitorowanie leczenia są niezbędne, aby zapewnić bezpieczne i efektywne wykorzystanie leku. W trakcie prowadzenia terapii powinno się monitorować dwa razy w roku morfologię krwi, stężenie methemoglobiny oraz markerów wątrobowych [14]. W przypadku nietolerancji dapsonu w leczeniu alternatywnie można zastosować sulfapirydynę, połączenie tetracykliny z nikotynamidem lub cyklosporynę. Leczenie należy stosować do końca życia. W badaniach wykazano, że większość pacjentów jest niezdolna do tolerowania glutenu nawet po wieloletnim stosowaniu diety eliminacyjnej. W związku z tym dożywotnia dieta bezglutenowa jest uzasadniona u wszystkich pacjentów z DH [16].

\section{KONFLIKT INTERESÓW}

Autorzy nie zgłaszają konfliktu interesów.

\section{References}

\section{Piśmiennictwo}

1. Weston W.L., Morelli J.G.: Dermatologia pediatryczna. A. Kaszuba (ed. Polish edition). Elsevier Urban \& Partner, Wrocław, 2013.

2. Jabłońska S., Majewski S.: Choroby skóry i choroby przenoszone drogą płciową. PWZL, Warszawa, 2005, 254-258.

3. Burgdorf W.H.C., Plewig G., Wolff H.H., Landthaler M.: Dermatologia Braun-Falco. W. Gliński, M. Czarnecka-Operacz, D. Krasowska, A.B. Serwin, H. Wolska H (eds. Polish edition). Czelej, Lublin, 2011.

4. Mendes F.B.R., Hissa-Elian A., Abreu M.A.M.M., Goncalves V.S.: Review: dermatitis herpetiformis. An Bras Dermatol 2013, 88, 594-599.

5. Fry L.: Dermatitis herpetiformis. Baillière. Clin Gastr 1995, 9, 371-394.

6. Humbert P.H., Pelletier F., Dreno B., Puzenat E., Aubin F.: Gluten intolerance and skin diseases. Eur J Dermatol 2006, 16, 4-11.

7. Wojnarowska F., Eady R.A.J., Burge S.: Bullous eruptions. In: Textbook of Dermatology. $6^{\text {th }}$ ed. R.H. Champion, J.L. Burton, D.A. Burns, S.M. Breathnach (eds.). Blackwell Science, London, 1998, 1817-1892.

8. Lionel F.R.Y.: Dermatitis herpetiformis: problems, progress and prospects. Eur J Dermatol 2002, 12, 523-531.

9. Chorzelski T.P., Beutner E.H., Sulej J., Tchorzewska H., Jablonska S., Kumar V., et al.: IgA-antiendomysium antibody. A new immunological marker of dermatitis herpetiformis and coeliac disease. Br J Dermatol 1984, 111, 395-402.

10. Rose C., Dieterich W., Bröcker E.B., Schuppan D., Zillikens D.: Circulating autoantibodies to tissue transglutaminase differentiate patients with dermatitis herpetiformis from those with linear IgA disease. J Am Acad Dermatol 1999, 41, 957-961.

11. Sulkanen S., Halttunen T., Laurila K., Kolho K.L., Korponay-Szabó I.R., Sarnesto A., et al.: Tissue transglutaminase autoantibody enzyme linked immunosorbent assay in detecting celiac disease. Gastroenterology 1998, 115, 1322-1328.

12. Sárdy M., Kárpáti S., Péterfy F., Rásky K., Tomsits E., Zágoni T., et al.: Comparison of a tissue transglutaminase ELISA with the endomysium antibody test in the diagnosis of gluten-sensitive enteropathy. Z Gastroenterology 2000, 38, 295-300.

13. Warren S.J., Cockerell C.J.: Characterization of a subgroup of patients with dermatitis herpetiformis with non-classical histologic features. Am J Dermatopathol 2002, 24, 305-308.

14. Żebrowska A., Waszczykowska E., Kowalewski C., Woźniak K., Olszewska M., Placek W., et al.: Diagnostic and therapeutic guidelines of dermatitis herpetiformis (Duhring's disease) - consensus of Polish Dermatological Society. Dermatol Rev 2016, 103, 95-101.

15. Katz S.I.: Dermatitis herpetiformis. In: Dermatology in General Medicine. $7^{\text {th }}$ ed. T.B. Fitzpatrick, A.Z. Eisen, K. Woff, I.M. Freedberg, K.F. Austen (eds.). McGraw-Hill, New York, 2010, 500-504.

16. Mansikka E., Hervonen K., Kaukinen K., Ilus T., Oksanen P., Lindfors K., et al.: Gluten challenge induces skinand small bowel relapse in long-term gluten-free diet-treated dermatitis herpetiformis. J Investig Dermatol 2019, 139, 2108-2114.

Received: 17.09 .2019

Accepted: 19.10.2019

Otrzymano: $17.09 .2019 \mathrm{r}$

Zaakceptowano: $19.10 .2019 \mathrm{r}$

How to cite this article

Skręta-Śliwińska M., Woźniacka A., Żebrowska A.: Haemorrhagic form of dermatitis herpetiformis

Dermatol Rev/Przegl Dermatol 2020, 107, 69-77. DOI: https://doi.org/10.5114/dr.2020.93974. 